\title{
Factors Related to Operational of Marina in West Coast Malaysia
}

\author{
Syahmi Firdaus Zamri, Ahmad Faizal Ahmad Fuad, Mohd Hafizi Said \\ Nautical Science and Maritime Transportation Program/Universiti Malaysia Terengganu \\ 21030 Kuala Nerus, Terengganu, Malaysia, +609-6683790 \\ e-mail:faizalfuad75@gmail.com
}

\begin{abstract}
Marina is a mooring facility or port located on a body of water that provides service for a small boat and yacht. The marinas in Malaysia are managed by private companies and few by Marine Department Malaysia. There are successful marinas in Malaysia. However, some marinas failed. This study aims to identify the factors to establish a successful marina and to identify factors that certain marina is less performed or failed. To identify the factors, the literature review and survey is performed to marina operators in Malaysia. The method used to analyse the data was the Analytic Hierarchy Process (AHP). Results showed that the identified factor are the location, services, and facility are the most important to establish the marina. The factor has a relationship with others, and the high possibility factor should be taken to establish a marina.
\end{abstract}

Keywords: Marina Operational, Marina Malaysia

\section{Introduction}

\subsection{Background Research}

In the maritime industry, the most important things are the port and marina. These two places provide many facilities and services. Some of the services are berthing, power supply and maintenance. Although these places offer the same services, this place has a different ability to handle the size of vessels and function. Ports are the places for the large vessel and more to the cargo operation, freighters, and passenger while the marina is the places for the small boats and yachts. Globally, the marina is the place for leisure activity such as sailing event and yacht rental. The marina location is along the coast of rising population centres and resorts. The marina also can be located along the riverbanks that connected to the sea and inland. Some are stand-alone facilities, and they are also with the port complex. The marina offers inland and ground facilities to be rent. There are many largest and famous marinas in Europe. The largest marina in the world is Grand Harbour Marina that located at Malta, and one of the famous marinas is Yacht Club Monaco marina at Monaco. There is the accreditation for global marina named Gold Anchor Award. This use to improve the standard and user experience of the marina. There also create a benchmark for facilities, operations, and customer service in a marina. This award helps the boaters to decide the best place for their boat and provide marketing for an accredited marina.

In Malaysia, the marina also provides facilities and the services for small boats inland and aground and leisure activity. Besides that, some of the marinas are the yacht club. There are 26 marinas in Malaysia located in every state of Malaysia. The marinas are managed by Marine Department Malaysia, and some are private marinas. The main marina

This paper is presented in The $4^{\text {th }}$ International Conference on Maritime Education and Training

October $8^{\text {th }}$, 2020, Makassar, Indonesia 
in Malaysia is Langkawi Yacht Club at the Langkawi, Sutera Harbour, Sabah and Puteri Harbour, Johor Bahru. Although Malaysia has many marinas, its operation does not reach the same level. There is some successfully operated, and some are not. Report audit last year stated that about half a million has losses caused by the failure of marina operation. This happens because it does not have any yacht arrival and facilities damaged. Therefore, the research is to determine the factor of the establishment of the marina in Malaysia. Then the result will be used to identify the reason for the marina less performed than the others. This research will be focussing on the marina at west coast Malaysia and the Maritimes authorities.

\subsection{Literature Review}

Marina is a mooring facility or port located on a body of water that provides dockage, moorings, shelter, storage, fuel docks, supplies and maintenance services for boats, yachts and cabin cruisers that always provides direct walkway access for each boat and an adequate depth of water-based on Global Marina Institute. The facilities are most likely at the port, and the marina has additional services which are repair and maintenance. It is easier for a small boat or yacht owner and does not need to find another party. Seven marinas operate by the Malaysia Marine Department, and 19 are private marina. In Malaysia, the marina provides service and amenities from basic to high-end, organized international sailing events and integrated resort concept[9]. Most of the Marina that operates by marine department offers service of pontoon system, water and electricity supply, boat ramp, hard standing for the boat storage area, landscape area and dry berthing area while the private marina provides service of resort hotels, yacht club and organize the sailing event. The marina that is operated by the private sector is mostly the yacht club that offers leisure activity and organizes sailing event such as the Langkawi Yacht Club.

\subsubsection{Factor of the thriving marina}

The marina should be built based on market study and can give multiple functions for the boat owner and user [7]. The market demand, boat data and past report are the components that should be seen to establish a marina [3]. The thriving marina also able to respond to the changing of markets and plan for future modernization improvement [10]. This situation will help the client feel safe to place their boats at the marina.

Marina should have wide target sector other than boat activities [7]. The product, promotion, price, and place are the factor of marina thriving. The location, facilities, services, and promotions are the identified factor that should be taken to make marina successful.

\subsubsection{Marina Location}

The location of the marina should be located along the coastline and have access to the city [1]. It will help to provide the service for water and land. The marina should be built based on the locations and its purpose [1]. The consideration that needs to take for build marina is the location detail which is the wind, wave, geology, water depth and environment [11]. The currents, tide and depth, are the factors that need to identify to ensure the marina can run properly [8]. Spring and neap tide should be a measure to provide safe navigation for entering and leaving the marina [8]. The current speed and direction are important to avoid sediment precipitation at the marina locations [8]. This information must be determined to decide the purpose of the marina. Besides that, the 
marina location must be able to protect against bad weather, maintain their facility and docks.

Marina can be classified in many types based on its function, which is homeport marina, tourist destination marina, stopover marina, boatyard, yacht club, Venetian docks, anchorage [12]. The windy place will be suitable for leisure activity, sailing event and tourist destination and the other place can be the boatyard and anchorage place. Marina should offer leisure activities because the purpose of the marina is for tourist destinations [1]. Boaters prefer mild activities such as fishing, kayaks and diving after sail [6]. Tourist love to spend their holiday and water sports such as charter, windsurfing and skiing [6].

Furthermore, marina placed also have accessibility to the land and water [13]. It can become the attraction of the marina because the water can provide service for boat and the land will give advantage to business enterprise to run their business. It will help the boat owner to service their boat and get other needs in one place.

\subsubsection{Marina Facilities}

The facilities of the marina must be compatible with the current trends in the industry, the demand from boat owner and the site conditions [5]. The right facilities should be built based on consumer needs and reasonable price and fully operated [3]. Boaters are assumed to get facilities that are suitable with the industry trend and their boats [5]. It is important to fulfil the customer needs to make the marina successful.

The basic facilities for the marina are floating dock, boatyard, power supplies and fuel. The floating must either the fixed or portable floating docks based on the tidal range, wave, current and debris condition. It is important because the boat owner is seeking safe berthing [2]. Electric power should be located at preferred locations for boat and maintenance use [5]. The boatyard and power supplies use during berthing and maintenance.

Besides that, the other amenities are security such as security staff, dock lighting and surveillance equipment[5]. Safety and facilities are one of the aspects of designing a marina [7]. The supporting infrastructure in a marina is one of the most important factors for boat owner [2]. It will help to maintain the boat and the facilities at the marina.

Furthermore, the berthing facilities also must be fully equipped based on the capabilities of the boat size. Some of the main facilities at the marina are finger floats, walkways, marginal walkways, and power supplies. Those facilities are different based on the size of the ship. The highest number of facilities, the most excellent service that can offer for onshore service [14].

\subsubsection{Marina Service}

The facilities are the only extra part of the marina success, and the central part is the service provided for the marina [13]. Marina should be built based on the size of the boat and service that will be an offer to boat owner [1]. The service should be an offer to boat owner based on their needs, and the price must be reasonable [3]. The demands now need marina to provide service on water and land [7]. It will make the marina as a onestop centre for boaters.

The service should be offered based on marina consumer to make sure it is fully operated [3]. The service that can provide depends on the facilities at the marina. The marina service can be categorised to four types which are basic service, basic derived service, peripheral service and complimentary service [6]. The basic service is berthing and security service. Boat owner always concerns about protection for their boat and related equipment 
from danger and crime [4]. The Safety measure at the marina should be enforced to avoid vandalism without disturbance customer [5]. The derived service such as swimming pool and dry dock. The Complementary service is the recreational activities away from the sea.

\subsubsection{Marina Promotions}

Promotion is one of the factors that can increase the operation and gain for the marina. The promotion must be done with the cooperation of all marina in the country. Being individual will make the duplication of effort, inefficient utilization of resources and out of strategy to promote Malaysia to the boaters [15]. All marina in the country must have their cooperation to promote their package and the other marina. It will help all the marina in the country be in the same level of successfulness in their operation and economic sector.

Besides that, the marina also can promote leisure activity because not all the customers have a boat. Marina should be for all level of people [15]. Some of them come for a holiday. By doing this, it will attract the boaters and the resident or tourist to the marina.

The promotions of marina should be in current trends. Social media, mass media, website, club website, brochure and Word of Mouth Marketing are tools that use to promote marina.

\section{Research Method}

The research focuses on west coast Malaysia. It is conducted to Admiral Marina and Leisure Club, Port Dickson, and Pangkor Marina, Pangkor. Those are the private marina that offers services for boat and yacht.

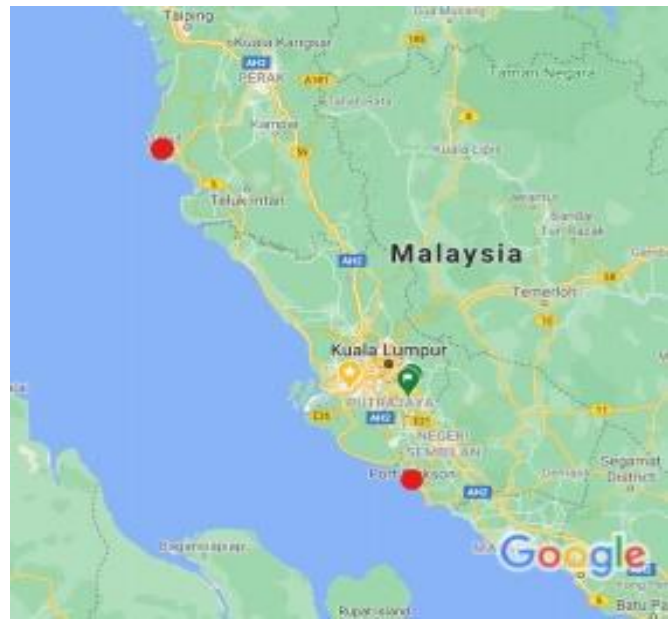

Figure 1: Area of Research (top red dots - Pangkor Marina, below red dot - Admiral Marina)

Figure 2 below shows the flowchart of the research activity during the study.

$\begin{array}{|ll|}\text { STEP } & \bullet \text { Literature Review } \\ 1 & \text { Sonstruct Analytic Hierarchy Process (AHP) Model } \\ \text { STEP } & \bullet \text { Cons } \\ 2 & \text { Develop Questionnaire } \\ \text { STEP } & \bullet \text { Develo } \\ 3 & \text { Survey Questionnaire To Expert } \\ \text { STEP } & \bullet \text { Survey } \\ 4 & \text { Data Analysis } \\ \text { Step } & \bullet \text { Data } \\ 5 & \end{array}$

Figure 2: Flowchart of Research Activity 
The literature review is used to achieve the first objective, which is to identify the factors to establish a marina. A lot of readings from previous publications, earliest study and mass media should be done to find the factor. The data from that reading is us to achieve the second objective. The second objective is to determine the reason certain marina less successful. The last objective of this research can be achieved by using the Analytic Hierarchy Process (AHP) software. There is some step that needs to be done to achieve it.

Firstly, the factor that has been gathered will be arranged accordingly to construct the Analytic Hierarchy Process (AHP) model. Literature review and expert engagement is the method to gather all the information.

Next, the factor that has been obtained is put in the Analytic Hierarchy Process (AHP) software to construct the model and questionnaire. The questionnaire is distributing to marina operators in the area of study. The criteria for the survey's respondent are as follows: a person holding a managerial post in a marina, a person with a substantial experience in managing marina operation, and a person that manages the yacht's charter operation in a marina. Survey has been conducted to the management of Admiral Marina and Leisure Club, Port Dickson and Pangkor Marina, Pangkor. Both marinas are privately owned.

The questionnaire requires the respondent to differentiate the most important between the factor. For the model, it contains a goal, criteria, and sub-criteria. By using the AHP method, valid data were obtained for all two respondents who are experienced in marina management and operation. Data obtained from AHP will determine the weight of our function variability. Hence, data gain for the weight of our function of variability will be analysed again by using AHP software to obtain the rank level factor of the successful marina.

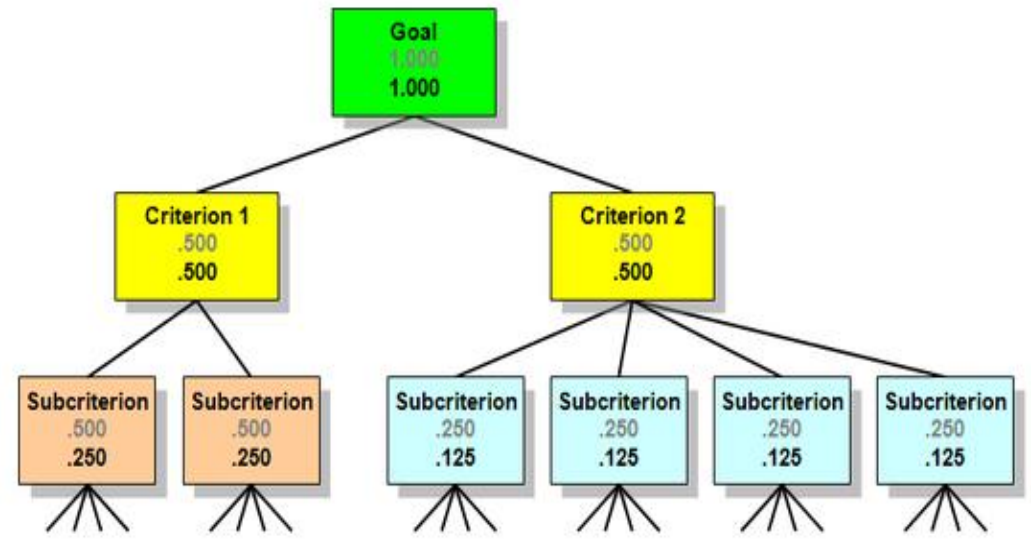

Figure 3: Analytic Hierarchy Process (AHP) Model

\section{Results and Analysis}

\subsection{AHP Model}

This model has been constructed after the information has been put in AHP Software. Level 0 is the goal of this model. Level 1 is the criteria, and level 2 are the subcriteria of level 1. 


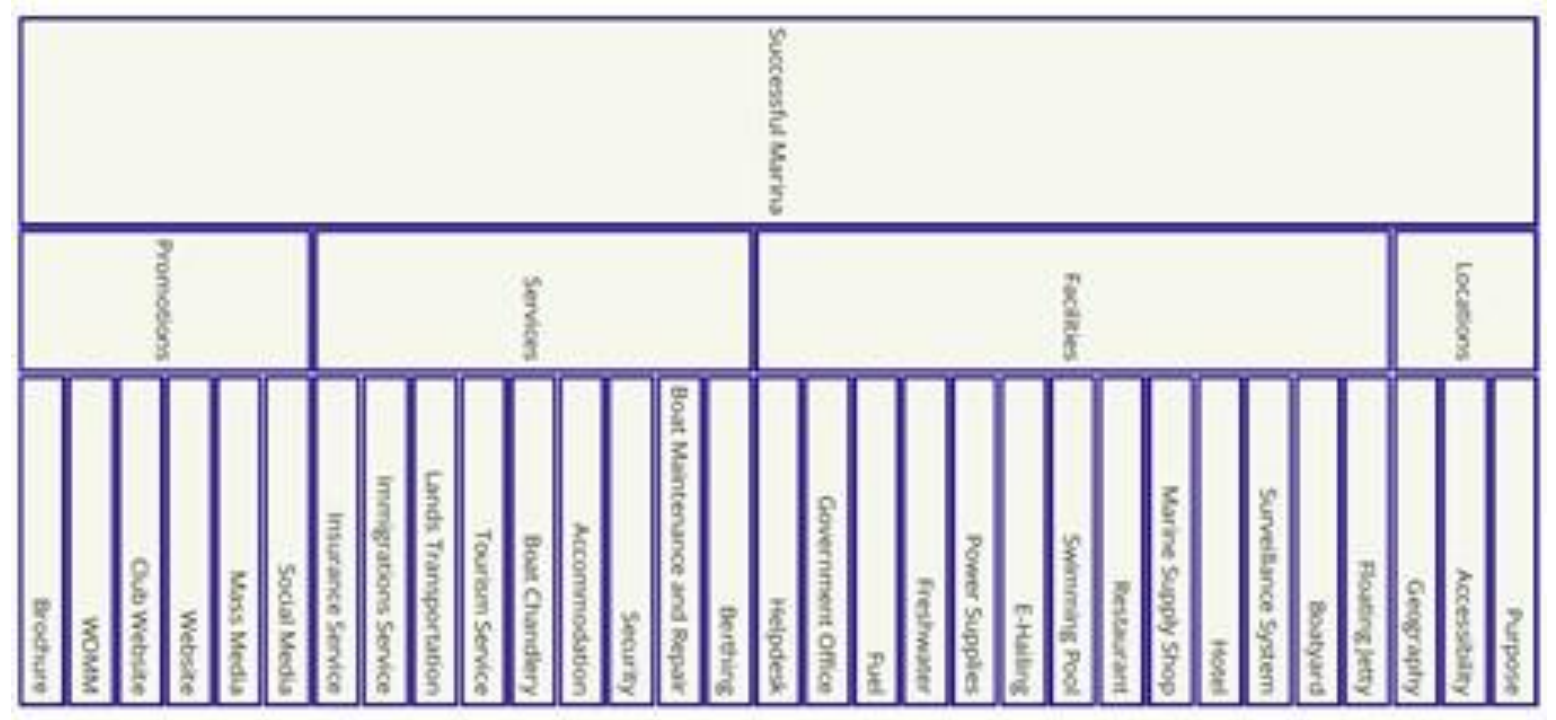

Figure 3: AHP Model of Successful Marina

\subsection{Result on Weight Stage}

i) Weight Stage (Main criteria)

Table 1 shows a summary of all two respondents on weight stage (main criteria). The value of consistency ratio is $3.6 \%$ which is less than $10 \%$ hence it is valid data. It concludes that the services $(57.9 \%)$ are the most important factor followed by locations (16.4\%), facilities $(15.8 \%)$, and promotions $(9.8 \%)$.

Table 1. Weight stage of main criteria

\begin{tabular}{cccccc}
\hline Participants & Locations & Facilities & Services & Promotions & CR $_{\max }$ \\
\hline Group Result & $16.4 \%$ & $15.8 \%$ & $57.9 \%$ & $9.8 \%$ & $3.6 \%$ \\
Respondent 1 & $5.5 \%$ & $5.0 \%$ & $71.7 \%$ & $17.8 \%$ & $14.8 \%$ \\
Respondent 2 & $32.1 \%$ & $32.1 \%$ & $32.1 \%$ & $3.6 \%$ & $0.0 \%$ \\
\hline
\end{tabular}

\section{ii) Weight Stage (Sub criteria 1)} locations).

Table 2 shows a summary of all two respondents on weight stage (sub-criteria

The value of consistency ratio is $14.1 \%$ which is more than $10 \%$ hence it is not valid data. It concludes the geography $(46.0 \%)$ is the most important factor, followed by purpose $(31.9 \%)$ and accessibility $(22.1 \%)$.

Table 2. Weight stage of sub-criteria (Locations)

\begin{tabular}{ccccc}
\hline Participants & Purpose & Accessibility & Geography & CR $_{\max }$ \\
\hline Group Result & $31.9 \%$ & $22.1 \%$ & $46.0 \%$ & $14.1 \%$ \\
Respondent 1 & $33.3 \%$ & $33.3 \%$ & $33.3 \%$ & $0.0 \%$ \\
Respondent 2 & $28.1 \%$ & $13.5 \%$ & $58.4 \%$ & $58.5 \%$ \\
\hline
\end{tabular}

\section{iii) Weight Stage (Sub criteria 2)}

Table 3 shows a summary of all two respondents on weight stage (sub-criteria facilities). The value of consistency ratio is $10.4 \%$ which is more than $10 \%$ hence it is not valid data. It concludes the floating jetty is the most important factor followed by

This paper is presented in The $4^{\text {th }}$ International Conference on Maritime Education and Training 56 October $8^{\text {th }}$, 2020, Makassar, Indonesia 
freshwater, marine supply shop, government office, fuel, helpdesk, boatyard, power supplies, restaurant, e-hailing/bus/taxi, hotel, and swimming pool.

Table 3. Weight stage of sub-criteria (Facilities)

\begin{tabular}{cccccccc}
\hline Participants & $\begin{array}{c}\text { Floating } \\
\text { Jetty }\end{array}$ & Boatyard & $\begin{array}{c}\text { Surveillance } \\
\text { System }\end{array}$ & Hotel & Restaurant & $\begin{array}{c}\text { Swimming } \\
\text { Pool }\end{array}$ & $\mathrm{Cr}_{\max }$ \\
\hline $\begin{array}{c}\text { Group } \\
\text { Result }\end{array}$ & $14.7 \%$ & $7.9 \%$ & $6.5 \%$ & $4.5 \%$ & $9.0 \%$ & $5.3 \%$ & $10.4 \%$ \\
$\begin{array}{c}\text { Respondent } \\
1\end{array}$ & $14.9 \%$ & $8.4 \%$ & $4.6 \%$ & $4.7 \%$ & $11.4 \%$ & $3.9 \%$ & $46.8 \%$ \\
$\begin{array}{c}\text { Respondent } \\
2\end{array}$ & $17.5 \%$ & $6.0 \%$ & $7.2 \%$ & $7.2 \%$ & $6.0 \%$ & $7.2 \%$ & $5.3 \%$ \\
\hline $\begin{array}{c}\text { Participants } \\
\text { Bus/Taxi/ }\end{array}$ & Power & Freshwater & Fuel & $\begin{array}{c}\text { Government } \\
\text { Office }\end{array}$ & Helpdesk & $\mathrm{Cr}_{\max }$ \\
\hline $\begin{array}{c}\text { Group } \\
\text { Result }\end{array}$ & $5.2 \%$ & $7.5 \%$ & $9.4 \%$ & $8.4 \%$ & $8.9 \%$ & $8.3 \%$ & $10.4 \%$ \\
$\begin{array}{c}\text { Respondent } \\
1\end{array}$ & $4.0 \%$ & $7.4 \%$ & $10.6 \%$ & $9.2 \%$ & $9.9 \%$ & $8.1 \%$ & $46.8 \%$ \\
$\begin{array}{c}\text { Respondent } \\
2\end{array}$ & $6.0 \%$ & $7.2 \%$ & $7.2 \%$ & $7.2 \%$ & $7.2 \%$ & $7.2 \%$ & $5.3 \%$ \\
\hline
\end{tabular}

\section{iv) Weight Stage (Sub Criteria 3)}

Table 4 shows a summary of all two respondents on weight stage (sub-criteria services). The value of consistency ratio is $3.1 \%$ which is less than $10 \%$ hence it is valid data. It concludes the berthing and security $(17.7 \%)$ is the most important factor followed by boat chandlery (14.7), boat maintenance and repair $(13.8 \%)$, immigrations service $(10.9 \%)$, land transportations (7.0\%), tourism service (6.4\%), accommodation $(6.1 \%)$, and insurance service $(5.7 \%)$.

Table 4. Weight stage of sub-criteria (Services)

\begin{tabular}{|c|c|c|c|c|c|c|}
\hline Participants & Berthing & $\begin{array}{c}\text { Boat } \\
\text { Maintenance } \\
\text { and repair }\end{array}$ & Security & Accommodation & $\begin{array}{c}\text { Boat } \\
\text { Chandlery }\end{array}$ & $\mathrm{CR}_{\max }$ \\
\hline Group Result & $17.7 \%$ & $13.8 \%$ & $17.7 \%$ & $6.1 \%$ & $14.7 \%$ & $3.1 \%$ \\
\hline Respondent 1 & $24.5 \%$ & $13.9 \%$ & $24.4 \%$ & $2.7 \%$ & $16.3 \%$ & $13.2 \%$ \\
\hline Respondent 2 & $11.1 \%$ & $11.1 \%$ & $11.1 \%$ & $11.1 \%$ & $11.1 \%$ & $0.0 \%$ \\
\hline Participants & \multicolumn{2}{|c|}{$\begin{array}{l}\text { Tourism } \\
\text { Service }\end{array}$} & $\begin{array}{c}\text { Land } \\
\text { ransportation }\end{array}$ & $\begin{array}{l}\text { Immigrations } \\
\text { Service }\end{array}$ & $\begin{array}{l}\text { Insurance } \\
\text { Service }\end{array}$ & $\mathrm{CR}_{\max }$ \\
\hline Group Result & \multicolumn{2}{|c|}{$6.4 \%$} & $7.0 \%$ & $10.9 \%$ & $5.7 \%$ & $3.1 \%$ \\
\hline Respondent 1 & \multicolumn{2}{|c|}{$3.0 \%$} & $3.8 \%$ & $9.1 \%$ & $2.4 \%$ & $13.2 \%$ \\
\hline Respondent 2 & $11.1 \%$ & \multicolumn{2}{|c|}{$11.1 \%$} & $11.1 \%$ & $11.1 \%$ & $0.0 \%$ \\
\hline
\end{tabular}

\section{V) Weight Stage (Sub Criteria 4)}

Table 5 shows a summary of all two respondents on weight stage (sub-criteria promotions). The value of consistency ratio is $14.6 \%$ which is more than $10 \%$ hence it is not valid data. It concludes the website $(25 \%)$ is the most important factor followed by This paper is presented in The $4^{\text {th }}$ International Conference on Maritime Education and Training 57 October $8^{\text {th }}, 2020$, Makassar, Indonesia 
Word of mouth marketing (WOMM) (22.5\%), social media (20\%), mass media (17.4\%), club website $(8.4 \%)$ and brochure $(6.8 \%)$.

Table 5. Weight stage of sub-criteria (Promotions)

\begin{tabular}{cccccccc}
\hline Participants & $\begin{array}{c}\text { Social } \\
\text { Media }\end{array}$ & $\begin{array}{c}\text { Mass } \\
\text { Media }\end{array}$ & Website & $\begin{array}{c}\text { Club } \\
\text { Website }\end{array}$ & WOMM & Brochure & CR $_{\max }$ \\
\hline $\begin{array}{c}\text { Group } \\
\text { Result }\end{array}$ & $20.0 \%$ & $17.4 \%$ & $25.0 \%$ & $8.4 \%$ & $22.5 \%$ & $6.8 \%$ & $14.6 \%$ \\
$\begin{array}{c}\text { Respondent } \\
1\end{array}$ & $19.5 \%$ & $19.7 \%$ & $30.2 \%$ & $3.1 \%$ & $25.9 \%$ & $1.6 \%$ & $84.7 \%$ \\
$\begin{array}{c}\text { Respondent } \\
2\end{array}$ & $16.7 \%$ & $16.7 \%$ & $16.7 \%$ & $16.7 \%$ & $16.7 \%$ & $16.7 \%$ & $0.0 \%$ \\
\hline
\end{tabular}

\section{Discussion}

The result of AHP had concluded that the service category was the most important with the priority ranking of 0.579 . The purpose of the marina itself to provide services for boat and user [10]. Having huge and good facilities is not good enough if it cannot achieve the boaters demands. The result also concludes that marina management is put the priority on service. By providing a good service, it means that the marina has the proper facilities for running the service. As an example, a marina offered that berthing service for sure that they have the floating jetty/ pontoon and secure from bad weather.

Besides that, the overall weight had ranked that the service is hugely important than the other factor. Boat owners are seeking safety for their boat and equipment [14]. The marina needs to provide the security service for the boat because some of the boat owners left their boat for a long time. With that service, it will help to secure the boat and the related equipment such as the Very High Frequency (VHF) radio from damage and stolen.

Next is the boat chandlery, boat maintenance and repair, geography and immigration service are also on the high-ranking factor. Repair and maintenance service is really necessary to ensure the boat are safe during the next sailing. With the boat chandlery and repair service, it will make the marina as a one-stop centre for boaters. The importance of geography is to provide safe berthing for boats.

\section{Conclusion}

In conclusion, this research had identified the factor to establish a marina and the reason certain marina less successful. The main factor in establishing a marina is the location, facilities, services, and promotions. The data obtained from Pangkor Marina, Pangkor and Admiral Marina and Leisure Club, Port Dickson. The method used in this research is Analytic Hierarchy Process AHP which is ranked the factor based on criteria weights.

There also some other factor should be considering building a marina such as the socioeconomic for a certain place. It is because marina not only focuses on boat and yacht but also should be on people in the country. Besides that, marina should be put more focus on leisure, such as water sport to encourage people to come to their place.

\section{References}

[1] N. Khalid, C. Tourism, and K. Lumpur, "SETTING SAIL : POSITIONING," no. July, 2008. 
[2] S. Kinsella, L. Ap, and R. Middleton, "Current Trends in Marina Planning and Design Introduction Market \& Demand Planning Environmental Design Summary Questions," no. July, 2014.

[3] A. Raviv, S. Y. Tarba, and Y. Weber, "Strategic planning for increasing profitability: The case of marina industry," EuroMed J. Bus., vol. 4, no. 2, pp. 200-214, 2009, doi: 10.1108/14502190910976547.

[4] J. Kizielewicz and T. Lukovic, "The Phenomenon of the Marina Development to Support the European Model of Economic Development," TransNav, Int. J. Mar. Navig. Saf. Sea Transp., vol. 7, no. 3, pp. 461-466, 2013, doi: 10.12716/1001.07.03.19.

[5] D. Alkaya, I. Çobanoğlu, and B. Yeşil, "The effect of geological and geotechnical factors on the project design of coastal structures (Alanya Marina case study)," Int. J. Phys. Sci., vol. 6, no. 22, pp. 5243-5252, 2011, doi: 10.5897/IJPS11.576.

[6] N. K. Rivero, K. A. Dafforn, M. A. Coleman, and E. L. Johnston, "Environmental and ecological changes associated with a marina," Biofouling, vol. 29, no. 7, pp. 803-815, 2013, doi: 10.1080/08927014.2013.805751.

[7] M. H. Hasan, "Assess the Main Factors Affecting the International Marina of Taba Heights at the Gulf of Aqaba, Red Sea, Egypt," J. Water Resour. Prot., vol. 06, no. 01, pp. 22-28, 2014, doi: 10.4236/jwarp.2014.61004.

[8] N. Ross, "Key Marina Planning Issues, La Paz, Mexico,” 2003.

[9] Y. E. Lam González, C. J. León González, and J. de León Ledesma, "Highlights of consumption and satisfaction in nautical tourism .," Gestión y Ambient., vol. 18, no. 1, pp. 129-145, 2015.

[10]D. Uri, B. D. Bender, and D. S. Windsor, "Marina Study : Marina Facilities Planning At Two Case Study Locations," 1979.

[11]T. City et al., "City of Alexandria, Virginia MEMORANDUM," 2017.

[12] S. Škorić, S. Favro, and N. Šerić, "Strategic guidelines for the development of marinas in the segment of mega-yachts in the Republic of Croatia," Turizam, vol. 22, no. 4, pp. 157-167, 2018, doi: 10.5937/turizam22-17398.

[13]R. Tsuneyoshi, "Guidelines for Marina Berthing Facilities - Layout and Design," no. July, p. 139, 2005.

[14]F. O. Sari, C. Bulut, and I. Pirnar, "Adaptation of hospitality service quality scales for marina services," Int. J. Hosp. Manag., vol. 54, pp. 95-103, 2016, doi: 10.1016/j.ijhm.2016.02.004.

[15]N. KHALID, A. S. ZAMIL, F. FARID, and S. N. I. ISHAK, "an Assessment of the Development," pp. 1-43, 2010. 